\title{
PENERAPAN ASAS NASIONALITAS DALAM PERUNDANG-UNDANGAN AGRARIA INDONESIA (STUDI KASUS PP NO.40 TAHUN 1996)
}

\author{
J um Anggriani \\ Fakultas Hukum Universitas Tama J agakarsa, J akarta \\ Email: jumanggriani@yahoo.com
}

\begin{abstract}
The Agrarian law regulated that only the Indonesian citizen that have the complete connection with the earth, water and the sky. This means that only Indonesian citizen that have "the rightful autority of land". This suggests there are a principle of nationality in the Law no. 5 years 1960 primarily as the strongest and fullest of a hereditary property.
\end{abstract}

Keywords : nationality principle, public service, welfare state.

\begin{abstract}
Abstrak
Undang-Undang Pokok Agraria (UUPA) menyebutkan bahwa hanya warga negara Indonesia yang dapat mempunyai hubungan sepenuhnya dengan bumi, air dan ruang angkasa. Penjabarannya adalah bahwa hanya warganegara Republik Indonesia yang dapat memilik "hak milik atas tanah". Hal ini menunjukkan adanya prinsip nasionalitas dalam UUPA terutama sebagai hak milik turun temurun yang terkuat dan terpenuh.
\end{abstract}

Kata kunci : asas nasionalitas, pelayanan masyarakat, negara kesejahteraan

\section{Pendahuluan}

Negara Indonesia adalah negara kesatuan yang terdiri dari beribu-ribu pulau dan lautan yang luas. Wilayah yang luas ini perlu dilindungi agar tetap menjadi daerah kekuasaan negara Indonesia. Pemerintah Indonesia kemudian membuat peraturan-peraturan yang dimaksudkan untuk melindungi dan mempertahankan hak milik bangsa ini.

Salah satu yang terpenting dari hak milik bangsa dan negara Indonesia adalah tanah. Persoalan tanah menjadi sangat penting, karena menyangkut tempat untuk berpijak dan berjuang untuk kelangsungan hidup warga masyarakat. Oleh karena itu, sewaktu membuat UUD negara ini, the founding fathers atau para pendiri negara merumuskan hal penting ini dalam UUD sebagai landasan dari peraturan-peraturan dibawahnya. Pasal 33 ayat 3 UUD 1945 yang membahas masalah pertanahan ini, menyebutkan bahwa bumi, air dan ruang angkasa dikuasai oleh negara dan dipergunakan untuk sebesarbesarnya kemakmuran rakyat. Kata "dikuasai" ini sangat penting, karena menyangkut hajat hi- dup orang banyak. Hal ini dapat diinterpretasikan bahwa pada dasarnya negara (dalam hal ini para aparatur negara) bukanlah sebagai pemilik tanah di Indonesia (dalam pengertian bumi dan segala kekayaan yang terkandung didalamnya). Negara hanya berstatus menguasai dan bukan memiliki, karena hak memiliki seluruh bumi Indonesia itu berada di tangan seluruh rakyat Indonesia, sehingga pemerintah harus bijak dalam mengeluarkan peraturan-peraturan yang berhubungan dengan tanah, jangan sampai peraturan-peraturan yang dibuat itu berten-tangan dan tidak sejalan dengan ketentuan-ketentuan yang telah digariskan dalam UUD.

Rumusan Pasal 33 ayat 3 UUD 1945 menggunakan istilah "bumi" dan bukan tanah. Hal ini menunjukkan bahwa yang dimaksud bumi adalah bagian dari permukaan bumi yang menjadi wilayah Indonesia. Namun dalam banyak hal, istilah "bumi" juga banyak diartikan sebagai tanah. Masalah tanah merupakan masalah yang sangat sensitif, sehingga harus ditangani secara hati-hati. Oleh karena itu, untuk mewujudkan maksud dan makna yang terkandung dari Pasal 
33 ayat 3 UUD 1945, maka pemerintah Indonesia mengeluarkan UU No. 5 Tahun 1960 tentang Peraturan Dasar Pokok-pokok Agraria (untuk selanjutnya ditulis UUPA).

Hak atas tanah diantaranya diatur pada Pasal 16 UUPA, meliputi hak milik, hak guna usaha (HGU), hak guna bangunan (HGB), hak pakai, hak sewa, hak membuka tanah, hak memungut hasil hutan dan hak-hak lainnya yang akan ditentukan dalam undang-undang serta hak yang bersifat sementara sebagaimana yang diatur pada Pasal 53 UUPA. Ketentuan tentang hak pakai atas tanah diatur pada Pasal 41 sampai dengan Pasal 43 UUPA. Dalam ketentuan tentang hak pakai atas tanah ini disebutkan bahwa selain warga negara Indonesia, maka warga negara asing dan badan usaha asing dapat mendapatkan hak pakai atas tanah ini. Ketentuan tentang hak guna usaha diatur pada Pasal 28 sampai dengan Pasal 34 UUPA, sedangkan ketentuan tentang hak guna bangunan diatur pada Pasal 35 sampai dengan Pasal 40 UUPA. HGU dan HGB hanya dapat dimiliki oleh warga negara Indonesia saja, sedangkan warga negara asing tidak dapat memiliki hak ini.

Peraturan Pemerintah No. 40 Tahun 1996 tentang Hak Guna Usaha, Hak Guna Bangunan dan Hak Pakai Atas Tanah. Ketentuan-ketentuan yang berhubungan dengan asas nasionalitas dalam PP ini diatur pada Bab IV tentang Pemberian Hak Pakai. Bagian ketujuh dari bab ini, yaitu tentang Peralihan Hak Pakai sangat menarik untuk dikaji, karena menyangkut akan kedudukan asas nasionalitas. Apakah hak pakai itu dapat dialihkan atau beralih? dan apakah ketentuan ini berlaku pula untuk warga negara Indonesia saja atau juga berlaku untuk warga negara asing dan badan usaha asing?. Beberapa pertanyaan tersebut muncul, karena belum tegas dan jelas diatur pada PP No. 40 Tahun 1996 dan menjadi kekurangan dari PP ini.

Pada dasarnya PP No. 40 Tahun 1996 ini memuat banyak muatan politik, sehingga ketentuan-ketentuan yang tertuang didalamnya dianggap belum memenuhi syarat, karena dibuat untuk kepentingan politik terutama politik ekonomi. Pemerintah beranggapan, bahwa bila para investor dari luar negeri diberi kelongga- ran dalam memiliki hak untuk mempergunakan tanah untuk usaha di Indonesia, maka investor luar negeri akan datang berbondong-bondong ke Indonesia untuk berinvestasi. Pemerintah waktu itu beranggapan dengan masuknya modal dari luar negeri, maka akan menggairahkan perekonomian Indonesia, sehingga Indonesia bisa mengejar ketertinggalannya dari negara-negara maju lainnya.

Berdasarkan penjelasan tersebut, penulis tertarik untuk membahas mengenai kedudukan asas nasionalitas dalam perundang-undangan agraria Indonesia, apakah ketentuan tentang cara peralihan hak pakai dari PP No.40 Tahun 1996 dapat dikenakan untuk orang atau badan usaha asing? dan bagaimana ketentuan tentang HGU dan HGB dalam PP No. 40 Tahun 1996 berkaitan dengan asas nasionalitas?

\section{Pembahasan}

Konsepsi negara hukum untuk mencapai negara kesejahteraan secara implisit terkandung di dalam UUD 1945 terutama Bab XIV tentang Kesejahteraan Sosial dan Pembukaan UUD 1945. Pada Pembukaan UUD 1945 alinea 4 tercermin tujuan dari negara Indonesia, yaitu: negara melindungi segenap bangsa dan seluruh tumpah darah Indonesia, memajukan kesejahteraan umum, mencerdaskan kehidupan bangsa, dan ikut melaksanakan ketertiban dunia yang berdasarkan kemerdekaan, perdamaian abadi dan keadilan sosial. Ketentuan-ketentuan di atas ini membawa dampak yang sangat besar terhadap kegiatan-kegiatan pemerintah dalam melaksanakan tujuan nasional. Dampak tersebut adalah kewenangan administrasi negara dalam penyelenggaraan pemerintahan dan pembangunan nasional yang membawa konsekuensi terlibatnya administrasi negara ke dalam semua aspek kehidupan masyarakat.

Melihat dari ketentuan tersebut, menjadikan negara mempunyai kewajiban untuk mewujudkan amanat UUD 1945 tersebut, yaitu meIalui campur tangan negara (freies ermessen) untuk memperluas tanggung jawabnya dalam masalah-masalah sosial yang dihadapi rakyat. Campur tangan pemerintah ini bertujuan untuk menyelenggarakan kesejahteraan bagi seluruh 
rakyat Indonesia, yaitu mewujudkan konsep negara kesejahteraan (Welfare State). ${ }^{1}$ Campur tangan tersebut tertuang dalam ketentuan perundang-undangan, baik dalam bentuk undangundang maupun peraturan pelaksanaan lainnya yang dilaksanakan oleh administrasi negara dalam menyelenggarakan tugas servis publik.

Negara mempunyai tanggungjawab yang besar, karenanya dengan jalan melalui campur tangan (intervensi), negara mengatur dan mengawasi pelaksanaan kegiatan yang ada di dalam masyarakat guna mencapai keseimba-ngan dalam masyarakat tersebut. Pemerintah harus memperhatikan, bahwa penyelenggaraan pemerintahan harus mengedepankan tujuan negara yaitu kesejahteraan seluruh rakyat Indonesia. Hal ini menjadi penting dalam konsepsi pengaturan tanah di Indonesia, terutama tentang ketentuan hak menguasai negara akan tanah, sehinga penjabaran dari ketentuan dalam Pasal 33 ayat (3) UUD 45 jo Pasal 2 UUPA haruslah bersifat populis.

Berdasarkan hal tersebut, sangat tidak diharapkan, apabila penjabaran pasal-pasal di atas diartikan sebagai kekuasaan negara yang seolah-olah tanpa batas, dimana negara sebagai penafsir tunggal terhadap hak menguasai. Jangan sampai terjadi, dengan berdalih untuk kepentingan umum, kepentingan pembangunan, kepentingan rakyat banyak, maka terjadi pelanggaran hak-hak tanah dalam UUPA yang digunakan untuk kepentingan pribadi, kelompok atau golongan serta pemodal baik dalam mau pun luar negeri. ${ }^{2}$

Negara dalam melakukan campur tangan ini harus tetap dalam kerangka negara hukum. Konsep negara hukum modern menempatkan negara pada posisi yang kuat dan besar, sehingga berbicara masalah negara hukum akan selalu timbul persoalan kekuasaan, terutama dalam usaha menjalankannya. Negara harus mendudukkan posisinya sebagai penyelenggara kese-

Jum Anggriani, "Analisis Petitum Batal atau Setidaktidaknya Tidak Sah", J urnal J udicial FH Utama J akarta, Volume II. No.2, Maret 2007, hlm. 1.

Ahmad Sodiki, "Politik Hukum Agraria: Unifikasi ataukah Pluralisme Hukum?", Jurnal Dinamika Hukum FH Universitas Islam Malang, TH.VII No.13, 2001, hlm.60 jahteraan umum atau negara melakukan tugas pelayanan kepada publik.

Negara harus bertindak atas kewenangan yang ada dalam melaksanaan tugas pelayanan kepada publik, yaitu berdasarkan aturan yang telah ditetapkan, dengan mengingat tata urutan dalam pembuatan peraturan perundangundangan, sebagaimana yang telah ditetapkan dalam Pasal 7 (1) Undang-undang No. 10 Tahun 2004 tentang Pembentukan Peraturan Perundang-undangan. Tata urutan peraturan perundang-undangan tersebut adalah: pertama, Undang-undang Dasar 1945; kedua, Undang-undang/Perpu; ketiga, Peraturan pemerintah; Keempat, Peraturan Presiden; dan kelima, Peraturan Daerah. Tata urutan peraturan perundang-undangan ini mengandung makna bahwa peraturan yang di atas menjadi dasar bagi pembentukan peraturan di bawahnya, sedangkan peraturan di bawah merupakan pelaksana aturan hukum di atas, sehingga materi muatannya tidak boleh bertentangan dengan atasnya dan dalam hal terdapat dua peraturan yang materi muatanya dan kedudukannya sama, maka yang berlaku adalah peraturan yang terbaru. ${ }^{3}$ Hirarkhi peraturan perundang-undangan di atas menjadi dasar bagi pembuatan aturan-aturan pertanahan di Indonesia, yang selalu bermuara kepada pembukaan UUD 1945 alinea ke-4 yaitu mencapai kesejahteraan rakyat.

Pemerintah Indonesia, dalam menjalankan tugasnya mencapai tujuan negara kesejahteraan, harus menjaga keutuhan dari wilayah yang dikuasainya. Dalam hal ini masalah tanah yang terkandung pula arti bumi dan seluruh yang ada di dalam dan diatasnya, sehingga diperlukan tindakan-tindakan pemerintah yang bertuj uan untuk kesejahteraan rakyat.

Masalah tanah adalah masalah yang sangat penting bagi kehidupan bermasyarakat, karena masalah tanah menjadi kebutuhan primer bagi manusia sebagai tempat bernaung dan berusaha. Terdapat dua kepentingan yang saling bertentangan bila berbicara menyangkut

\footnotetext{
3 Retno Saraswati, "Perkembangan Pengaturan Sumber Hukum dan Tata Urutan Peraturan Perundang-undangan Di Indonesia", Jurnal Media Hukum, Jumal IImiah Asosiasi Pengajar dan Praktisi IImu Hukum Semarang, April-J uni 2005, hlm. 17
} 
tanah, yaitu kepentingan pemerintah di satu sisi dan kepentingan masyarakat di sisi lainnya. Oleh karena itu, diperlukan pendekatan yang dapat diterima dan dimengerti masyarakat, apabila pemerintah akan mengeluarkan tindakan berupa pembuatan pengaturan yang berhubungan dengan tanah. Berdasarkan hal tersebut, maka perlu ditanamkan pengertian, bahwa tanah mempunyai fungsi sosial seperti yang ditegaskan di dalam Pasal 6 UUPA yang menyatakan bahwa semua hak atas tanah mempunyai fungsi sosial. ${ }^{4}$ Selain itu perlu juga diperhatikan bahwa pembaharuan agraria mencakup suatu proses yang berkesinambungan berkenaan dengan penataan kembali penguasaan, pemilikan, penggunaan dan pemanfaatan sumber daya agraria agar tercapainya kepastian dan perlindungan hukum serta keadilan dan kemakmuran bagi seluruh rakyat Indonesia. ${ }^{5}$

Tindakan pemerintah dalam membuat peraturan perundang-undangan harus berdasarkan tujuan negara yaitu welfare state (mencapai negara kesejahteraan), sehingga dalam pembuatan suatu undang-undang harus melibatkan Badan Perwakilan Rakyat (DPR) sebagai wakil dari rakyat, dan agar pelaksanaan hukum itu dapat mencapai tujuannya, maka diperlukan kekuasaan dari pemerintah untuk menjalankannya. Dalam hal ini harus ada keselarasan antara hukum di satu sisi dan kekuasaan untuk menjalankannya di sisi lain. ${ }^{6}$

Salah satu dari tindakan pemerintah ini adalah dengan dikeluarkannya UU No. 5 Tahun 1960 tentang Pokok-Pokok Agraria dan PP No. 40 Tahun 1996 tentang Hak Guna Usaha, Hak Guna Bangunan Dan Hak Pakai Atas Tanah. Dalam PP ini dibahas lebih mendalam tentang pelaksanaan dari ketiga hak diatas dengan UUPA dan UUD 1945 sebagai pedomannya.

Endang Sri Santi, "Pengadaan Tanah Untuk Pembangunan Perluasan Landasan Pacu Bandara Ahmad Yani Di Kota Semarang", J urnal Masalah-Masalah Hukum FH UNDIP Semarang, Desember 2004, hlm. 352.

5 Muchtar Luthfi, "Kedudukan Hukum Tanah Nasional Setelah Berlakunya UU No.22 tahun 1999 tentang Pemerintahan Daerah", J urnal Hukum Justice For All, FH Universitas Muhammadiyah J akarta, J uli 2002, hlm. 48.

6 J um Anggriani, "Hukum dan Kekuasaan”, J urnal Widya Yustisia Kopertis Wil. III, J akarta, Tahun VII No.2, J uliDesember 2005, hlm. 42.
Pembentukan PP No. 40 Tahun 1996 dilandasi kepentingan politik ekonomi, dimana dengan diberi kemudahan dalam pengaturan tentang HGB, HGU dan Hak Pakai bagi warga negara asing/ badan usaha asing sebagai pemilik modal, akan menanamkan investasinya di Indonesia, sehingga kegiatan perekonomian di Indonesia dapat berjalan dengan baik. Tindakan pemerintah ini harus dipayungi oleh landasan hukum yang benar agar tujuan negara meningkatkan perekonomian di Indonesia tepat sasaran yaitu mensejahterakan rakyat bukan mensejahterakan segelintir orang, apalagi warga negara asing/ badan usaha asing.

Pengaturan di bidang pertanahan agar sesuai dengan kebutuhan bangsa, maka perlu memenuhi prinsip-prinsip yang menjadi acuan bagi peraturan agraria di Indonesia. Menurut Maria S.W. Sumardjono ${ }^{7}$, ada 10 prinsip yang menjadi landasan bagi pembaharuan hukum agraria, agar produk yang dihasilkan tepat sasaran, yaitu: pertama, menjunjung tinggi hak asasi manusia; kedua, unifikasi hukum yang mengakomodasikan keanekaragaman hukum setempat; ketiga, land reform atau restrukturisasi sumbersumber agrarian; keempat, keadilan dalam pemilikan/penguasaan dan pemanfaatan sumbersumber agrarian; kelima, fungsi sosial dan ekologi sumber-sumber agrarian; keenam, penyelesaian konflik agrarian; ketujuh, pembagian kewenangan antara pusat dan derah serta kelembagaan pendukung; kedelapan, transparansi dan partisipasi dalam pembuatan kebijakan; kesembilan, usaha-usaha produksi di lapangan agraria; dan kesepuluh, pembiayaan program-program pembaharuan agraria.

Ketentuan di dalam UUPA menyebutkan, bahwa hanya warga negara Indonesia yang dapat mempunyai hubungan sepenuhnya dengan bumi, air dan ruang angkasa. Penjabarannya adalah bahwa hanya warga negara Republik Indonesia yang dapat memilik "hak milik atas tanah". Hal ini menunjukkan adanya prinsip nasionalitas dalam UUPA terutama sebagai hak milik turun temurun yang terkuat dan terpenuh.

Maria S.W. Sumardjono, "Penyempurnaan UUPA, di antara Dua Pilihan", J urnal Mimbar Hukum, FH UGM, Edisi Khusus No. 39/ X/2001, hlm. 266-268. 
Sifat terkuat dan terpenuh dari hak milik ini merupakan suatu sifat kebendaan (zakelijk karakter) yang berarti bahwa hak milik itu dapat beralih dan dialihkan kepada orang lain, dapat dibebani hak tanggungan dan dapat dijadikan jaminan hutang dan karena mempunyai sifat-sifat itu pula, maka hal ini memberikan arti kepada di pemegang hak milik, yaitu pemegang hak milik atau pemilik tanah hak untuk berbuat bebas atas tanah miliknya itu. Hal ini berarti bahwa pemilik tanah mempunyai hak untuk mengasingkan atau memindahtangankan tanahnya itu dengan jalan menukarkan, mewariskan, menghibahkan atau menjualnya kepada orang lain atau kepada suatu badan hukum.

Asas nasionalitas yang dianut UUPA sepenuhnya tertuang dalam pengaturan tentang hak milik. Warga negara Indonesia yang dapat mempunyai hak milik atas tanah, sedangkan warga negara asing hanya dapat memiliki hak pakai atas tanah saja. Makna Pasal 1 dan 2 UUPA dengan demikian akan terpenuhi.

Hak guna Usaha (HGU) adalah hak untuk mengusahakan tanah yang dikuasai oleh negara, jadi obyeknya adalah tanah negara, adapun obyeknya adalah warga negara Indonesia dan badan hukum Indonesia, sedangkan yang dimaksud dengan Hak Guna Bangunan (HGB) adalah hak untuk mengusahakan dan mempunyai bangunan atas tanah bukan milik sendiri. Subyek hukum HGB sama dengan HGU yaitu warga negara Indonesia dan badan hukum Indonesia. Kedua hak ini dapat dialihkan, asalkan kepada WNI atau badan hukum Indonesia.

Ketentuan-ketentuan tentang HGB dan HGU diatur dalam peraturan perlaksananya yaitu PP No. 40 Tahun 1996, hanya sayangnya peraturan ini dianggap belum memenuhi syarat, karena dibuat untuk memenuhi kepentingan politik, yaitu untuk menarik investor dari luar negeri agar mau menanamkan modalnya di Indonesia. Kemudahan-kemudahan yang ada dalam bidang pemakaian pertanahan di Indonesia, diharapkan dengan para investor akan berbondong-bondong masuk ke Indonesia, sehingga perekonomian Indonesia diharapkan akan maju dan berkembang pesat.
Hukum agraria pada dasarnya adalah hukum yang mengatur tentang tanah dan segala sesuatu yang berhubungan dengan pertanahan, misalnya hal perairan, perikanan, perkebunan, pertambangan dan sebagainya. Adapun menurut Black's Law Dictionary, hukum agraria adalah perangkat peraturan hukum yang bertujuan mengadakan pembagian tanah-tanah yang luas dalam rangka lebih meratakan penguasaan dan pemilikan tanah. Hukum agraria menurut UUPA adalah kelompok berbagai bidang hukum yang masing-masing mengatur hak-hak penguasaan atas sumber-sumber daya alam tertentu yang termasuk ke dalam pengertian agraria.

Berdasarkan penjelasan tersebut, dapat disimpulkan bahwa hukum agraria adalah hukum yang mengatur tentang tanah dan segala sesuatu yang berhubungan dengan tanah tersebut. Landasan hukum agraria adalah pasal 33 ayat (3) UUD 45, yang mengatur bahwa bumi dan air dan kekayaan alam yang terkandung di dalamnya dikuasai oleh negara dan dipergunakan untuk sebesar-besarnya kemakmuran rakyat, serta untuk mencapai kebahagiaan hidup yang tertib, aman dan sejahtera berdasarkan landasan idiil Pancasila. ${ }^{8}$ Bumi, air dan kekayaan alam yang terkandung dalam bumi adalah pokok-pokok kemakmuran rakyat. Oleh karena itu, harus dikuasai oleh negara dan dipergunakan untuk sebesar-besar kemakmuran rakyat.

Ruang lingkup pertanahan beserta segala seluk beluknya tersebut, menurut UUPA secara terinci dapat dijabarkan sebagai berikut: pertama, seluruh bumi, selain mempunyai pengertian permukaan bumi (yang disebut tanah), termasuk pula tubuh bumi dibawahnya serta bagian bumi yang berada dibawah air; kedua, seluruh air, dalam arti perairan, baik perairan pedalaman maupun laut wilayah Republik Indonesia; ketiga, seluruh ruang angkasa, dalam arti ruangan yang ada di atas bumi dan air tersebut di atas; keempat, sumber-sumber kekayaan alam yang terkandung di dalam air, baik perairan pedalaman maupun perairan laut wilayah Republik Indonesia misalnya ikan dan sebangsa-

8 Sutrisno, "Politik Hukum Perlindungan Pengelolaan Lingkungan Hidup", Jurnal Hukum lus Quia lustum, FU UII Yogyakarta, J uli 2011, hlm. 449. 
nya, berbagai bangsa binatang laut lainnya, garam, mutiara, teripang dan sebagainya (Pasal 1 ayat (2), (6), Pasal 4 dan Pasal 5 UUPA). Hasilhasil alam Indonesia yang menjadi sumber penghidupan bangsa dan negara secara garis besarnya dapat dijabarkan dalam lima sektor terpenting yaitu pertanian, perkebunan, perhutanan, peternakan dan pertambangan.

Hukum positif telah mengatur, bahwa tanah dikualifikasikan sebagai "permukaan bumi", sedangkan pengertian bumi sendiri adalah termasuk tanah dan tubuh bumi dibawahnya, serta yang berada di bawah air. Peraturan perundangan di Indonesia, hanya mengatur permukaan bumi saja (tanah) yang dapat dimiliki perorangan.

Sesuai dengan pengertian dari hukum, maka hak menguasai itu pada umumnya dapat melekat pada dua jenis subyek hukum, yaitu masyarakat atau penguasa dan perorangan. Dalam hal ini, penguasa dapat bertindak selaku penguasa, dapat pula bertindak sebagai subyek hukum. Dilihat dari sudut intensitasnya, maka hak menguasai itu bisa bergerak dari kadar yang paling lemah sampai kepada bobot yang paling kuat, seperti hak pakai, memetik kemudian menikmati hasil, hak memelihara/mengurus/ mengelola, hak milik sampai kepada hak mengasingkan dalam segala bentuk.

Pembentukan sebuah peraturan yang mengatur tentang agraria bukan sesuatu yang mudah, sehingga baru pada tahun 1960 UUPA baru dapat diundangkan. Dalam memori penjelasan atas rancangan UUPA disebutkan tujuan pokok UUPA yaitu: pertama, meletakkan dasar-dasar bagi penyusunan hukum agraria nasional yang akan merupakan alat untuk membawakan kemakmuran, kebahagiaan dan keadilan bagi negara dan rakyat tani, dalam rangka masyarakat yang adil dan makmur; kedua, meletakkan dasar-dasar untuk mengadakan kesatuan dan kesederhanaan dalam hukum pertanahan, dan ketiga, meletakkan dasar-dasar untuk memberikan ke-pastian hukum mengenai hak-hak atas tanah bagi rakyat seluruhnya. Dasar-dasar dari hukum agraria nasional sendiri yaitu pertama, prinsip kesatuan dalam hukum agraria untuk seluruh wilayah tanah air; kedua, penghapusan asas domein dan penerapan hak menguasai negara; ketiga, fungsi sosial hak atas tanah; keempat, pengakuan hukum agraria nasional berdasarkan hukum adat dan pengakuan eksistensi hak ulayat; kelima, persamaan derajat sesama WNI dan antara laki-laki dan wanita; keenam, pelaksanaan reform hubungan antara manusia dengan tanah atau bumi, air dan ruang angkasa; ketujuh, rencana umum penggunaan, persediaan dan pemeliharaan bumi, air dan ruang angkasa; dan kedelapan, prinsip atau asas nasionalitas.

Kewenangan negara untuk mengelola kekayaan alam Indonesia dalam bidang pertanahan didasarkan pada hak menguasai negara yang pelaksanaanya dilakukan sehari-hari oleh pemerintah, baik di pusat maupun di daerah. Pelaksanaan hak menguasai negara ini tidak boleh bertentangan dengan kepentingan nasional, undang-undang dan peraturan perundang-undangan lainnya dan harus tetap mengingat pelaksanaan hak-hak adat yang dalam kenyataannya masih ada didalam masyarakat.

Pembangunan yang berkaitan dengan bidang pertanahan saat ini masih banyak menimbulkan permasalahan dan sangat merugikan rakyat banyak yang seharusnya dilindungi hak-haknya atas tanah yang mereka miliki. Kepentingan umum yang terkandung dalam bidang pertanahan, dalam hal ini khususnya adalah kepentingan rakyat Indonesia secara umumnya.

Berkaitan dengan masalah kepentingan umum, terdapat suatu prinsip yang mengatur penggunaan atau penggunaan hak atas tanah, yaitu "semua hak atas tanah mempunyai fungsi sosial" (lihat Pasal 6 UUPA). Keperluan tanah tidak diperbolehkan semata-mata untuk kepentingan pribadi, kegunaannya harus disesuaikan dengan keadaannya dan sifat dari haknya, sehingga bermanfaat untuk masyarakat dan kepentingan negara. Hak atas tanah yang berfungsi sosial ini meliputi semua hak atas tanah. Pemilikan dan penggunaan tanah tanpa batas tidak diperkenankan agar untuk tidak merugikan kepentingan umum (lihat Pasal 7 UUPA).

Asas merupakan jiwa dari suatu norma. Walaupun asas tidak mempunyai kekuatan hukum yang mengikat, tetapi asas menjadi jiwa 
dari suatu peraturan atau norma. Terdapat 7 (tujuh) asas yang dikenal dalam UUPA, yaitu asas penguasaan oleh negara, asas fungsi sosial, asas hukum adat, asas nasionalitas dan kesederajatan, asas larangan pemilikan tanah melampaui batas, asas perencanaan umum dan asas pemeliharaan tanah dan dapat dijelaskan sebagai berikut.

Pertama, asas penguasaan oleh negara. Asas penguasaan oleh negara dilandasi oleh ketentuan Pasal 33 ayat (3) UUD 1945, yang pada intinya memberikan kewenangan dan kekuasaan atas sumber daya alam dan seluruh kekayaan alam untuk kemakmuran rakyat. Hak menguasai negara atas bumi, air dan ruang angkasa ini diatur dalam ketentuan Pasal 1 jo Pasal 2 ayat (2) UU No.5 Tahun 1960 (UUPA). Menurut ketentuan pasal tersebut, negara sebagai organisasi kekuasaan tertinggi diberi kewenangan untuk: mengatur dan menyelenggarakan peruntukan, penggunaan, persediaan dan pemeliharaan bumi, air dan ruang angkasa; menentukan dan mengatur hak-hak yang dapat dipunyai atas bumi, air, ruang angkasa; dan menentukan dan mengatur hubungan-hubungan hukum antara orang-orang dan perbuatan-perbuatan mengenai bumi, air dan ruang angkasa.

Kedua, asas fungsi sosial. Asas fungsi sosial terdapat dalam pasal 6 UUPA yang mengatakan bahwa setiap tanah mempunyai fungsi sosial. Seseorang tidak boleh semata-mata mempergunakan hak atas tanah miliknya untuk kepentingan pribadi saja, tetapi harus memperhatikan kepentingan orang lain disekitarnya. Selain itu, penggunaan tanah miliknya tidak boleh merugikan masyarakat, dengan kata lain penggunaan dan pemanfaatan tanah harus disesuaikan dengan keadaannya dan sifat dari haknya, sehingga bermanfaat, baik untuk kesejahteraan pemegang hak, maupun bagi masyarakat dan negara.

Ketiga, asas hukum adat. Menurut Pasal 5 UUPA, hukum agraria yang berlaku atas bumi, air dan ruang angkasa ialah hukum adat. Berdasarkan ketentuan ini dapat diinterpretasikan, bahwa hukum tanah nasional (UUPA) berdasarkan kepada hukum adat, dengan kata lain, hukum tanah nasional itu ialah hukum adat. Hukum adat merupakan sumber utama untuk memperoleh bahan-bahan dalam rangka membangun hukum tahan nasional berupa konsepsi, asas-asas dan lembaga-lembaga hukumnya untuk dirumuskan menjadi norma-norma hukum yang tertulis yang disusun menurut sistem hukum adat.

Keempat, asas nasionalitas. Ketentuan Pasal 9 UUPA mengarur, bahwa hanya warga negara Indonesia saja yang boleh mempunyai hubungan sepenuhnya dengan bumi, air dan ruang angkasa. Ketentuan ini diperjelas dengan ayat (2) yang mengatur bahwa baik laki-laki maupun wanita mempunyai kesem-patan yang sama untuk memperoleh suatu hak atas tanah.

Kelima, asas larangan Pemilikan Tanah Melampaui Batas. Ketentuan tentang asas ini diatur dalam Pasal 7 UUPA jo Pasal 17 yang mengatur, bahwa untuk tidak merugikan kepentingan umum, pemilikan dan penguasaan tanah yang melampaui batas tidak diperkenankan. Larangan ini disebut juga larangan latifundia.

Keenam, asas perencanaan umum. Ketentuan tentang perencanaan ini terdapat dalam rumusan Pasal 14 UUPA yang mengatur bahwa pemerintah harus membuat suatu rencana umum mengenai persediaan, peruntukkan dan penggunaan bumi, air dan ruang angkasa.

Ketujuh, asas pemeliharaan tanah. Asas tentang pemeliharaan tanah diatur dalam Pasal 15 UUPA yang mengatur, bahwa tiap-tiap pemegang hak atas tanah mempunyai kewajiban untuk memelihara termasuk menambah kesuburan tanah dan mencegah kerusakannya.

\section{Hak-hak Atas Tanah dalam UUPA}

Hak-hak atas tanah dalam UUPA pada dasarnya adalah hak kebendaan, yaitu hak yang secara langsung menguasai suatu kebendaan dan kekuasaan itu dapat dipertahankan terhadap setiap orang, sehingga dengan demikian disebut hak mutlak (absolut). Hak-hak atas tanah yang disebutkan dalam UUPA diatur daIam ketentuan Pasal 16, yang diuraikan pada bagian di bawah ini.

Pertama, Hak Milik. Hak milik adalah suatu hak atas tanah yang terpenuh, terkuat dan paling sempurna, diantara hak-hak atas 
tanah lainnya. Hak milik harus mempunyai fungsi sosial, seperti halnya fungsi tanah lainnya (Pasal 6 UUPA). Hak milik atas tanah tersebut di samping memberikan manfaat bagi pemiliknya juga bermanfaat untuk kepentingan umum. Selain itu, penggunaan tanah tersebut tidak boleh mengganggu ketertiban dan kepentingan umum. Hak milik atas tanah ini harus dapat menempatkan kehidupan manusia dalam taraf keserasian antara dimensi individual dan dimensi sosialnya. Pemilik tanah mempunyai hak untuk berbuat "bebas", artinya boleh mengasingkan tanah miliknya pada pihak lain dengan menjualnya, menghibahkannya, menukarkan dan mewariskan. Hak milik hanya dapat dimiliki oleh Warga negara Indonesia (Lihat Pasal 20 - Pasal 27 UUPA).

Kedua, Hak Guna Usaha. Hak guna usaha adalah suatu hak yang memberikan wewenang kepada pemegangnya untuk mengusahakan tanah yang langsung dikuasai oleh negara untuk kegiatan-kegiatan pertanian, perikanan atau peternakan, ketentuan ini terdapat di dalam Pasal 28 UUPA. Hak guna usaha ini dapat dijadikan sebagai jaminan hutang, dipindahtangankan dan dialihkan kepada ahli waris. Hak guna usaha yang dikuasai oleh negara, jangka waktunya adalah 25 tahun atau 35 tahun untuk perusahaan, dan dapat diperpanjang maksimal 25 tahun (ketentuan ini telah diubah menjadi 35 tahun dan dapat diperpanjang paling lama 25 tahun, untuk kemudian dapat diperbaharui kembali, terdapat dalam PP No. 40 Tahun 1996 tentang Hak Guna Bangunan Dan Hak Pakai Atas Tanah). Hak guna usaha dapat dimiliki oleh WNI atau badan hukum yang didirikan menurut hukum Indonesia dan berkedudukan di Indonesia (Lihat Pasal 28 - Pasal 34 UUPA).

Ketiga, Hak Guna Bangunan. Hak guna bangunan adalah suatu hak yang memberikan wewenang kepada pemegangnya untuk dapat mendirikan bangunan di atas tanah yang bukan miliknya sendiri, baik tanah itu merupakan milik orang atau pihak lain maupun berupa tanah yang langsung dikuasai negara (Pasal 35 - Pasal 40 UUPA). Jangka waktu hak guna bangunan paling lama 30 tahun dan dapat diperpanjang maksi-mal 20 tahun. Subyek hak ini adalah WNI atau badan hukum yang didirikan menurut hukum Indonesia dan berkedudukan di Indonesia. Hak guna usaha dapat dijadikan sebagai jaminan hutang, memindahtangankan, hak mengalihkannya kepada ahli waris selama jangka waktunya belum habis.

Keempat, Hak Pakai. Hak pakai yaitu suatu hak yang memberikan wewenang kepada pemegangnya untuk menggunakan tanah pihak lain untuk keperluan penggunaan apa saja, seperti untuk ditanami atau didiami dan didirikan bangunan diatasnya selama waktu tertentu menurut perjanjian (Pasal 41 - Pasal 43 UUPA), sedangkan terhadap tanah, bisa milik perorangan atau milik negara. Dalam hal yang terakhir, maka hak pakai dalam UUPA dapat analogikan dengan hak pakai adat. Hak ini diberikan dalam jangka waktu tertentu atau selama tanah tersebut digunakan untuk keperluan tertentu, dengan cuma-cuma, dengan pembayaran atau pemberian jasa berupa apapun. Subyek hak pakai adalah WNI, badan hukum yang didirikan menurut hukum Indonesia dan bertempat tinggal di Indonesia, Departemen, Lembaga pemerintah non departemen dan pemerintah daerah, badan-badan keagamaan dan sosial, orang asing yang berkedudukan di Indonesia, badan hukum asing yang mempunyai perwakilan di Indonesia, perwakilan negara asing dan perwakilan badan internasional. Tanah yang dapat diberikan dengan hak pakai adalah tanah negara, tanah hak pengelolaan dan tanah hak milik. J angka waktu hak pakai atas tanah negara dan hak pengeloIaan maksimal 25 tahun dan dapat diperpanjang maksimal 20 tahun atau tidak ditentukan jangka waktunya selama masih dipergunakan untuk keperluan tertentu (lihat Pasal 45 PP No. 40 Tahun 1996).

Kelima, Hak Sewa. Hak sewa untuk bangunan adalah suatu hak yang memberikan wewenang bagi pemegangnya untuk mempergunakan tanah milik orang lain guna keperluannya mendirikan bangunan di atas tanah tersebut. Subyek hak ini adalah WNI, orang asing yang berkedudukan di Indonesia, atau badan hukum asing yang mempunyai perwakilan di Indonesia. Hak sewa tidak memiliki batasan waktu untuk pemakaiannya (lihat Pasal 44 dan 
Pasal 45 UUPA). Keenam, Hak Membuka Tanah dan Hak Memungut Hasil Hutan. Kedua hak ini terdapat diatur pada Pasal 46. Hak ini hanya diperuntukkan bagi WNI saja.

Ketujuh, Hak-Hak Atas Tanah Yang Bersifat Sementara. Hak ini diatur dalam ketentuan Pasal 53 UUPA yang mengkualifikasikan menjadi tiga hak, yaitu hak gadai, hak usaha bagi hasil dan hak menumpang. Hak gadai merupakan suatu hak yang dipegang oleh seorang kreditur yang memberikan wewenang kepadanya untuk menguasai tanah debiturnya dan turut menikmati atau mengambil hasilnya selama si debitur itu belum dapat melunasi hutangnya. Tanah ini dapat berupa tanah pertanian dan tanah untuk bangunan. Hak usaha bagi hasil, yaitu hak yang memberikan wewenang kepada seorang penggarap untuk dapat mengerjakan atau mengusahakan tanah milik orang lain dengan memberikan sebahagian tertentu dari jumlah hasil tanah tersebut kepada pemiliknya menurut perjan-jian. Hak menumpang, yaitu suatu hak yang memberikan kewenangan kepada seseorang atau suatu pihak untuk menumpang tinggal di atas tanah milik orang lain baik dengan menempati bangunan yang sudah ada maupun dengan membangun sendiri bila seandainya tersebut masih kosong.

\section{Kedudukan Asas Nasionalitas dalam Perun- dang-undangan Agraria Indonesia}

Dualisme hukum yang mengatur pertanahan terjadi di Indonesia sebelum dikeluarkannya UUPA, yaitu orang yang tunduk pada hukum Belanda (BW) dan penduduk pribumi yang tunduk pada hukum adat. Pada masa ini penduduk Hindia Belanda dibagi dalam tiga golongan yaitu golongan Eropa, China atau Timur asing dan pribumi. Dualisme hukum dan penggolongan penduduk ini sengaja diciptakan untuk keuntungan perekonomian Belanda saja. Golongan Timur Asing diperlukan sebagai tenaga pemasaran produk Belanda yang dikuras dari bumi Indonesia yang dijual keluar negeri, sedangkan golongan pribumi dibiarkan dalam hukum adatnya sendiri, agar tidak mencampuri hukum tanah yang dibuat oleh Belanda sendiri.
Keadaan yang merugikan bangsa Indonesia ini kemudian melatarbelakangi pemerintah untuk membuat suatu tindakan hukum, yaitu dengan mengeluarkan UUPA. Pemberlakuan UUPA yang memuat prinsip/asas nasionalitas dimaksudkan untuk melindungi rakyat Indonesia dari ketidakadilan dan perbuatan sewenang-wenang penjajah Belanda. UUPA mengatur bahwa seluruh wilayah Indonesia adalah kesatuan tanah air dari seluruh rakyat Indonesia, yang bersatu sebagai bangsa Indonesia. Seluruh bu$\mathrm{mi}$, air dan ruang angkasa, termasuk kekayaan alam yang terkandung didalamnya sebagai karunia dari Tuhan Yang Maha Esa. Hubungan antara bangsa Indonesia dan bumi, air serta ruang angkasa tersebut adalah hubungan yang bersifat abadi (Pasal 1 dan Pasal 2 UUPA).

Ketentuan tentang asas nasionalitas terdapat dalam Pasal 1, 2, 9, 20 ayat (1), 21 ayat (2), 30 ayat (1), 31 ayat (1), dan pasal 46 ayat (1). Pemahaman akan prinsip atau asas nasionalitas dapat dilihat dalam ketentuan Pasal 9 UUPA yang intinya mengatur bahwa hanya WNI yang dapat mempunyai hubungan sepenuhnya dengan bumi, air dan ruang angkasa. Setiap WNI, mempunyai kesempatan yang sama untuk memperoleh hak atas tanah serta untuk mendapatkan manfaat dan hasilnya.

Rumusan ketentuan Pasal 9 UUPA merupakan pernyataan bahwa hanya warganegara Indonesia saja yang berhak memiliki tanah di Indonesia, sedangkan warga negara asing atau badan usaha asing hanya dapat mempunyai hak atas tanah yang terbatas saja, seperti hak pakai. Orang asing, termasuk perwakilan perusahaan asing, hanya dapat mempunyai hak atas tanah yang terbatas, selama kepentingan WNI tidak terganggu dan juga perusahaan orang asing itu dibutuhkan untuk kepentingan Negara Indonesia, sebagai komponen tambahan dari pembangunan ekonomi Indonesia dan apabila dihubungkan dengan Pasal 5 UUPA, maka kepentingan WNI adalah di atas segalanya, baik dari segi ekonomis, sosial bahkan politis.

Kepemilikan tanah bangsa Indoensia agar tidak beralih kepada orang asing/badan usaha asing, maka di dalam UUPA diatur tentang pemindahan hak atas tanah terhadap orang asing, 
yaitu tidak diperbolehkannya terjadi jual beli hak atas tanah, karenanya jika terjadi jual beli hak atas tanah kepada orang asing maka jual beli itu batal karena hukum, sedangkan status tanahnya akan jatuh kepada negara, dengan ketentuan bahwa hak-hak lain yang diterima oleh pemilik tidak dapat dituntut kembali ${ }^{9}$. Hal ini dapat dilihat di dalam ketentuan Pasal 26 (2) UUPA yang mengatur, bahwa setiap jual beli, penukaran, penghibahan, pemberian yang dimaksud untuk langsung atau tidak langsung memindahkan hak milik kepada orang asing, kepada seorang warga negara yang di samping kewarganegara-an asing atau kepada suatu badan hukum kecuali yang ditetapkan oleh pemerintah termasuk dalam Pasal 21 ayat (2) adalah batal karena hukum dan tanahnya jatuh kepada negara dengan ketentuan, bahwa pihak-pihak yang membebaninya tetap berlangsung, serta semua pembayaran yang telah diterima oleh pemilik tidak dapat dituntut kembali.

Indonesia adalah negara yang sedang membangun, dengan kondisi ekonomi rakyat yang masih rendah, apalagi saat ini sedang diterpa dengan multi krisis, moneter, ekonomi, politik dan sosial budaya, belum lagi konflik kedaerahan. Oleh karena itu, diperlukan suatu perlindungan terhadap hak milik, terutama tanah, agar tanah-tanah dalam wilayah negara ini tidak jatuh ketangan orang asing.

Prinsip atau asas nasionalitas dalam UUPA ini secara khusus diterapkan pada hak milik atas tanah yang mempunyai sifat kebendaan (zakelijk karakter), sehingga wajar apabila hak milik hanya disediakan untuk warga negara Indonesia. Prinsip nasionalitas dalam UUPA menekankan bahwa hanya warga negara Indonesia mempunyai hubungan yang sepenuhnya dengan bumi, air dan ruang angkasa, sehingga orang asing sebagaimana hak yang pernah mereka miliki yaitu boleh mempunyai hak-hak atas di Indonesia asal mau tunduk kepada BW dan peraturan-peraturan keperdataan telah ditinggalkan. Dalam hukum Indonesia yang berlaku saat ini, dibedakan antara Warga Negara Indonesia dengan pihak asing, sehingga tidak ada jalan keluar apapun

9 Soedharyo Soimin, 2004, Status Hak dan Pembebasan Tanah, J akarta: Sinar Grafika, hlm. 97 untuk melegalkan orang asing mempunyai hubungan yang sepenuhnya dengan bumi, air dan ruang angkasa dan kekayaan alam yang terkandung di dalamnya, sama dengan WNI.

Berdasarkan penjelasan tersebut dapat kita lihat bahwa hanya warga negara Indonesia saja yang boleh memiliki hak milik atas tanah, hal ini dapat dilihat dari ketentuan Pasal 21 ayat (1), yaitu hanya warganegara Indonesia yang dapat mempunyai hak milik. Hak milik merupakan hak turun temurun, terkuat dan terpenuh yang dapat dipunyai orang atas tanah tanpa mengabaikan fungsi sosial dari tanah. Ketentuan tentang hak milik ini terdapat di dalam Pasal 20 ayat (1).

Ketentuan tentang asas nasionalitas daIam UUPA juga dapat dilihat dalam ketentuanketentuan dalam Pasal 30 ayat (1) yang mengatur bahwa hak guna usaha dimiliki oleh WNI dan badan hukum yang didirikan menurut hukum Indonesia dan berkedudukan di Indonesia. Ketentuan lainnya terdapat di dalam Pasal 36 ayat (1) yang mengatur bahwa hak guna bangunan dimiliki oleh WNI dan badan hukum Indonesia yang didirikan menurut hukum Indonesia dan berkedudukan di Indonesia. Asas nasionalitas juga terdapat di dalam Pasal 46 ayat (1) yang mengatur, bahwa hak membuka tanah dan memungut hasil hutan hanya dapat dipunyai oleh wara negara Indonesia.

Berdasarkan penjelasan tersebut, dapat disimpulkan bahwa kedudukan asas nasionalitas dalam UUPA sangat penting karena menyangkut hak warga negara Indonesia untuk memiliki bumi, air dan ruang angkasa yang berada di wilayah negara kesatuan Republik Indonesia. Negara hanya mempunyai kewenangan untuk menguasai saja untuk kepentingan dan kesejahteraan rakyat Indonesia, sedangkan yang memiliki kekayaan tersebut adalah rakyat Indonesia.

Ketentuan tentang asas nasionalitas dalam PP No.40 Tahun 1996 dapat dilihat yaitu dengan ketentuan tidak diberikannya hak-hak tertentu atas tanah bagi orang asing atau badan usaha asing, hak-hak itu seperti hak milik, hak guna usaha dan hak guna bangunan. Dalam ketentuan tentang HGB dan HGU disebutkan bahwa yang dapat memiliki HGU dan HGB 
adalah warga negara Indonesia dan badan hukum yang didirikan menurut hukum Indonesia dan berkedudukan di Indonesia (Pasal 2 dan 19 PP No.40 Tahun 1996). Hal ini penting diatur dengan hati-hati, karena HGU dan HGB sebagaimana hak milik adalah hak atas tanah yang memiliki sifat kebendaan, sehingga dapat beralih dan dialihkan kepada pihak lain, sebagaimana ketentuan di dalam Pasal 16 tentang HGU dan Pasal 34 tentang HGB yang mengatur bahwa peralihan kedua hak ini dapat terjadi karena jual beli, tukar menukar, penyertaan dalam modal, hibah dan pewarisan.

Hak guna usaha berakhir karena waktunya telah berakhir, melanggar syarat pemberian, dilepas haknya, dicabut haknya untuk kepentingan umum, tanahnya musnah, melanggar prinsip nasionalitas/bukan warga negara atau badan hukum Indonesia lagi (lihat Pasal 34 UUPA jo PP No.40 Tahun 1996). Hak guna bangunan sendiri berakhir karena jangka waktunya telah berakhir, dihentikan sebelum jangka waktu berakhir, dilepas oleh pemegang hak, dicabut untuk kepentingan umum, ditelantarkan, tanah musnah, bukan warga negara atau badan hukum Indonesia lagi (Lihat Pasal 30 ayat (2) UUPA jo Pasal 20 PP No.40 Tahun 1996).

Berdasarkan penjelasan tersebut, dapat dilihat bahwa PP No.40 Tahun 1996 memuat juga tentang asas nasionalitas. Hal ini tampak dari ketentuan yang tidak memberikan hak guna usaha dan hak guna bangunan kepada orang asing, walaupun PP ini berisi banyak kelonggaran untuk orang asing, tetapi ketentuan asas nasionalitas tetap dijalankan.

\section{Peralihan Hak Pakai Kepada Orang Asing atau Badan Usaha Asing Menurut PP No.40 Tahun 1996.}

Pengertian mengenai hak pakai terdapat di dalam Pasal 41 UUPA yang mengatur bahwa hak pakai adalah hak untuk menggunakan dan/ atau memungut hasil dari tanah yang dikuasai langsung oleh negara atau tanah milik orang lain, yang memberi wewenang dan kewajiban yang ditentukan dalam keputusan pemberiannya oleh pejabat yang berwenang memberikannya atau dalam perjanjian dengan pemilik ta- nahnya, yang bukan perjanjian sewa menyewa atau perjanjian mengolahan tanah, segala sesuatu asal tidak bertentangan dengan jiwa dan ketentuan-ketetnuan undang-undang ini. Sumber dari kewenangan hak pakai berdasarkan ketentuan Pasal 41 UUPA berasal dari tanah yang dikuasai oleh negara, dimana yang dapat memberikan hak pakai adalah pejabat yang berwenang. Selain itu, hak pakai atas tanah juga dapat diperoleh dari perorangan yang mempunyai hak milik atas tanah itu. Hak pakai ini diberikan berdasarkan perjanjian dengan pemilik tanah tersebut. Menurut UUPA, perjanjian tersebut haruslah bukan perjanjian sewa menyewa atau perjanjian pengolahan tanah. ${ }^{10}$

Menurut PP No. 40 Tahun 1996, hanya hak pakai saja yang dapat dimiliki oleh orang asing atau badan usaha asing. Hal ini sesuai dengan ketentuan Pasal 39 PP No.40 Tahun 1996. Ketentuan tentang hal ini berkaitan dengan asas nasionalitas, yaitu untuk mencegah agar orang asing atau badan usaha asing tidak dapat mempunyai keterikatan yang erat dengan tanah di Indonesia.

Hak pakai yang dapat dimiliki oleh orang asing dan badan usaha asing diatur dalam Pasal 39 sampai dengan Pasal 58. Pasal 39 dan Pasal 40 mengatur tentang subyek dari hak pakai, sedangkan Pasal 41 mengatur tentang objek tanah yang dapat dikenakan hak pakai. Pasal 42 sampai dengan Pasal 44 mengatur tentang terjadinya hak pakai. Selanjutnya tentang jangka waktu hak pakai diatur dalam Pasal 45 sampai dengan Pasal 49. Adapun tentang kewajiban dan hak pemegang hak pakai diatur dalam Pasal 50 sampai dengan Pasal 52, sedangkan Pasal 53 mengatur tentang pembebanan hak pakai dan Pasal 54 mengatur tentang peralihan hak milik. Terakhir ketentuan tentang hak pakai ini adalah ketentuan-ketentuan yang diatur dalam Pasal 55 sampai Pasal 58 yang berisi tentang hapusnya hak pakai.

Peralihan hak pakai diatur dalam ketentuan Pasal 54 PP No. 40 Tahun 1996. Menurut ketentuan ayat (1) hak pakai yang diberikan

10 Kartini Muljadi dan Gunawan Widjaja, 2008, Hak-Hak Atas Tanah, Kencana, Jakarta: Prenada Media Group, hlm. 246. 
atas tanah negara untuk jangka waktu tertentu dan hak pakai atas tanah hak pengelolaan dapat beralih dan dialihkan pada pihak lain, sedangkan ayat (2) mengatur bahwa hak pakai atas tanah hak milik hanya dapat dialihkan apabila hak tersebut dimungkinkan dalam perjanjian pemberian hak pakai atas tanah hak milik yang bersangkutan. Peralihan hak milik terjadi karena jual beli, tukar menukar, penyertaan dalam modal, hibah dan pewarisan. dan wajib didaftarkan pada kantor pertanahan. Rumusan Pasal 54 kontradiksi dengan Pasal 1, sehubungan dengan ketentuan akan asas nasionalitas. Menurut ketentuan Pasal 1 yang mengatur bahwa hak pakai dapat beralih dan dialihkan pada pihak lain. Pengertian dapat beralih disini berarti dapat beralih dengan sendirinya seperti contohnya warisan, jadi hak pakai itu dapat beralih dengan sendirinya pada ahli warisnya.

Ketentuan tentang dapat beralih dalam Pasal 54 ayat (1) PP No.40 Tahun 1996 ini bertentangan dengan dengan Pasal 43 ayat (2) UUPA yang mengatur bahwa hak pakai hanya dapat dialihkan kepada pihak lain, jika hal itu dimungkinkan dalam perjanjian yang bersangkutan. Berdasarkan ketentuan UUPA ini, dapat kita lihat kata-kata dialihkan yang berkonotasi harus seijin pemilik tanah. Kata dialihkan juga mempunyai pengertian selalu dilakukan dengan perbuatan hukum, sedangkan kata beralih tidak harus dilakukan dengan perbuatan hukum. Ketentuan Pasal 54 ini juga bertentangan dengan asas nasionalitas, karena dengan ketentuan pasal ini dapat saja orang asing atau badan usaha milik asing mengalihkan hak pakainya dengan dalih ketentuan ayat (1) yang memperbolehkan mereka untuk mengalihkan hak pakai tersebut. Kalau sudah demikian, apa bedanya hak pakai ini dengan hak milik.

\section{Ketentuan tentang Hak Guna Bangunan dan Hak Guna Usaha dalam PP No. 40 Tahun 1996 Berkaitan dengan Ketentuan Hak Milik.}

Ketentuan tentang Hak Guna Bangunan (HGB) dan Hak Guna Usaha (HGU) ini berkaitan erat dengan asas nasionalitas, karena kedua hak ini adalah hak atas tanah yang memiliki sifat kebendaan, sehingga kedua hak ini dapat ber- alih dan dialihkan. Kedua hak ini hanya dapat diberikan kepada warga negara Indonesia dan badan hukum yang bertempat tinggal di Inonesia saja. Ketentuan tentang HGB dan HGU ini sama dengan ketentuan tentang hak milik. Hanya saja, bila hak milik, kepemilikannya mutlak dan tidak dapat diganggu gugat dan mempunyai akibat hukum yang pasti berupa surat hak milik (SHM).

Melihat dari ketentuan PP No. 40 Tahun 1996 ini, dapat diinterpretasikan bahwa tanah yang dapat diberikan untuk HGU adalah tanah negara, ketentuan ini terdapat dalam Pasal 4. J angka waktu yang diberikan untuk HGU ini di atur dalam Pasal 8 ayat (1) yang di mana HGU diberi jangka waktu paling lama 35 tahun dan dapat diperpanjang untuk jangka waktu paling lama 25 tahun. Sesudah jangka waktu tersebut berakhir, maka kepada pemegang hak dapat diberikan pembaharuan HGU di atas tanah yang sama.

Ketentuan tersebut secara tidak langsung menyamakan pengertian HGU dan Hak milik atas tanah, karena selain keduanya memiliki kesamaan tentang status tanah yaitu memiliki sifat kebendaan yang dapat beralih dan dialihkan, pembatasan jangka waktu kepemilikan HGU juga tidak jelas. Ketentuan Pasal 8 mengatur bahwa jangka waktunya tiga lima tahun ditambah dua puluh lima tahun sehingga menjadi enam puluh tahun, setelah itu masih dapat diperbaharui dengan jangka waktu yang tidak dibatasi. Kalau sudah begini apa bedanya HGU dengan hak milik atas tanah?

Ketentuan tentang HGB juga sama dengan HGU, status tanahnya juga berupa hak atas tanah yang memiliki sifat kebendaan, sehingga dapat beralih dan dialihkan. Dalam HGU, tanah yang dapat diberikan pada hak ini hanya tanah negara, sedangkan untuk HGB, tanah yang dapat diberikan adalah tanah negara, tanah hak pengelolaan dan tanah hak milik. Jangka waktu HGB menurut Pasal 25 ayat (1) adalah tiga puluh lima tahun ditambah dua puluh tahun sehingga berjumlah lima puluh lima tahun. Sesudah jangka waktu HGB berakhir, kepada bekas pemegang hak dapat diberikan pembaharuan HGB. Ketentuan tentang HGB ini seba- 
gaimana HGU, dalam pembaharuan haknya tidak ditentukan untuk waktu berapa kali pembaharuan. Kedua hak ini juga dapat diwariskan. Hal ini menjadikan HGU dan HGB statusnya tidak berbeda dengan hak milik atas tanah.

\section{Penutup}

Simpulan

Kedudukan asas nasionalitas sangat penting dalam peraturan perundang-undangan agraria di Indonesia, karena menyangkut kepentingan rakyat dan bangsa Indonesia untuk menjadi tuan rumah di tanahnya sendiri. Peralihan hak pakai pada orang asing atau badan usaha asing menurut PP No. 40 Tahun 1996 bertentangan dengan asas nasionalitas. Ketentuan tentang HGU dan HGB menurut PP No. 40 Tahun 1996 tidak berbeda dengan ketentuan tentang hak milik atas tanah, karena memiliki sifat kebendaan dan dapat diwariskan, selain itu pengaturan batasan jangka waktunya juga tidak jelas.

\section{Rekomendasi}

Berdasarkan penjelasan tersebut, penulis mengajukan rekomendasi agar ketentuan tentang hak pakai dalam PP No. 40 Tahun 1996 perlu di revisi, karena bertentangan dengan asas nasionalitas. Selain itu, perlu diadakannya pembaharuan terhadap PP No. 40 Tahun 1996, karena tidak jelasnya pengaturan akan batasan jangka waktu tentang HGU dan HGB.

\section{Daftar Pustaka}

Anggriani, Jum. "Analisis Petitum Batal atau Setidak-tidaknya Tidak Sah". J urnal J udicial, Vol. II. No.2, Maret 2007;
"Hukum dan Kekuasaan", J urnal Widya Yustisia Tahun VII No. 2, Juli-Desember 2005, Kopertis Wil.III, J akarta;

Luthfi, Muchtar. "Kedudukan Hukum Tanah Nasional Setelah Berlakunya UU No.22 tahun 1999 tentang Pemerintahan Daerah". Jurnal Hukum J ustice For All, Juli 2002. FH Universitas Muhammadiyah J akarta;

Muljadi, Kartini dan Gunawan Widjaja. 2008. Hak-Hak Atas Tanah. Jakarta: Kencana Prenada Media Group;

Santi, Endang Sri. "Pengadaan Tanah Untuk Pemba-ngunan Perluasan Landasan Pacu Bandara Ahmad Yani Di Kota Semarang". J urnal Masalah-Masalah Hukum, Desember 2004. FH UNDIP Semarang;

Saraswati, Retno. "Perkembangan Pengaturan Sumber Hukum dan Tata Urutan Peraturan Perundang-undangan Di Indonesia", Jurnal Media Hukum, April-J uni 2005. Jumal Ilmiah Asosiasi Pengajar dan Praktisi Ilmu Hukum Semarang;

Sodiki, Ahmad. "Politik Hukum Agraria: Unifikasi atau-kah Pluralisme Hukum?". J urnal Dinamika Hukum TH.VII No.13, 2001. FH Universitas Islam Malang;

Soimin, Soedharyo. 2004. Status Hak dan Pembebasan Tanah. J akarta: Sinar Grafika;

Sumardjono, Maria S.W. "Penyempurnaan UUPA, di Antara Dua Pilihan". J urnal Mimbar Hukum, Edisi Khusus No.39/X/2001. FH UGM;

Sutrisno. "Politik Hukum Perlindungan PengeIolaan Lingkungan Hidup". Jurnal Hukum Ius Quia lustum, Juli 2011. FU UII Yogyakarta; 